\title{
Research
}

\section{Endangered species management and ecosystem restoration: finding the common ground}

\author{
Michael L. Casazza ${ }^{1}$, Cory T. Overton $^{1}$, Thuy-Vy D. Bui ${ }^{1}$, Joshua M. Hull $^{2,3}$, Joy D. Albertson $^{2}$, Valary K. Bloom $^{4}$, Steven Bobzien $^{5}$, \\ ${ }_{\text {Jennifer McBroom }}{ }^{6}$, Marilyn Latta $^{7}, \underline{\text { Peggy Olofson }}^{8}$, Tobias M. Rohmer $^{6,9}, \underline{\text { Steven Schwarzbach }}^{1}$, Donald R. Strong ${ }^{10}$, Erik Grijalva \\ ${ }^{3}$, Julian K. Wood $^{11}$, Shannon M. Skalos ${ }^{1}$ and John Takekawa ${ }^{12}$
}

\begin{abstract}
Management actions to protect endangered species and conserve ecosystem function may not always be in precise alignment. Efforts to recover the California Ridgway's Rail (Rallus obsoletus obsoletus; hereafter, California rail), a federally and statelisted species, and restoration of tidal marsh ecosystems in the San Francisco Bay estuary provide a prime example of habitat restoration that has conflicted with species conservation. On the brink of extinction from habitat loss and degradation, and non-native predators in the 1990s, California rail populations responded positively to introduction of a non-native plant, Atlantic cordgrass (Spartina alterniflora). California rail populations were in substantial decline when the non-native Spartina was initially introduced as part of efforts to recover tidal marshes. Subsequent hybridization with the native Pacific cordgrass (Spartina foliosa) boosted California rail populations by providing greater cover and increased habitat area. The hybrid cordgrass $(S$. alterniflora $\times$ S. foliosa) readily invaded tidal mudflats and channels, and both crowded out native tidal marsh plants and increased sediment accretion in the marsh plain. This resulted in modification of tidal marsh geomorphology, hydrology, productivity, and species composition. Our results show that denser California rail populations occur in invasive Spartina than in native Spartina in San Francisco Bay. Herbicide treatment between 2005 and 2012 removed invasive Spartina from open intertidal mud and preserved foraging habitat for shorebirds. However, removal of invasive Spartina caused substantial decreases in California rail populations. Unknown facets of California rail ecology, undesirable interim stages of tidal marsh restoration, and competing management objectives among stakeholders resulted in management planning for endangered species or ecosystem restoration that favored one goal over the other. We have examined this perceived conflict and propose strategies for moderating harmful effects of restoration while meeting the needs of both endangered species and the imperiled native marsh ecosystem.
\end{abstract}

Key Words: ecosystem; endangered; restoration; California Ridgway's Rail; Spartina

\section{INTRODUCTION}

In the past few decades, conservation planning across the globe has shifted from single-species management to multispecies planning and ecosystem-based management as our understanding of ecological processes and appreciation of social-ecological systems has grown (Poff et al. 1997, Poiani et al. 2000). Conservation plans to preserve and recover endangered species often recognize that habitat loss, fragmentation, and/or degradation are the primary causes for endangerment (Wilcove et al. 1998, Venter et al. 2006). Consequently, special protections may be afforded to endangered species habitats to promote sustainable populations, and habitat restoration or enhancements are often among the actions identified as prerequisites for recovery (Kerr and Deguise 2004, Taylor et al. 2005).

Similarly, the field of restoration ecology has also developed rapidly (Zedler 1999, D'Antonio and Meyerson 2002, Ma et al. 2011, Suding 2011) and is often a centerpiece for ecosystem management planning to promote self-sustaining populations of native species and to restore both biodiversity and degraded ecosystem services (Rey Benayas et al. 2009). Techniques used to restore ecosystems include re-establishment of natural disturbance regimes (Baker 1992, Conway et al. 2010), flood cycles (Poff et al. 1997, Richter and Richter 2000), or invasive species eradication (D'Antonio and Meyerson 2002, MacDougall and Turkington 2005), among others. The criterion for success of ecosystem restoration is change from an existing undesired habitat condition toward a more desired condition and is often measured by a change in species composition, ecological function, or ecosystem service. However, how are these made and who gets to decide what is desired? Should this be a consensus-driven decision? What about legal authorities and minimum standards? Identifying who, or how, these desired future conditions are identified and measured is a nontrivial process. Whether these conditions are identified through consensus, legal mandate, or personal fiat, the final stated outcome, along with any minimum prerequisites, can greatly influence the efficiency, expediency, or expense of management actions.

Both preservation of endangered species and ecosystem restoration often incorporate vegetation management or habitat composition as measures of success. Although ecosystem restoration and species preservation may have different criteria for success, they are often compatible goals. They may even be necessary preconditions for mutual achievement of desired outcomes (Falk et al. 1996). However, both goals view habitat from a fundamentally different perspective.

Ecosystem restoration often considers habitat as a specific end product or a mechanism to provide broader ecosystem services or functions. By contrast, endangered species management may

${ }^{1}$ U.S. Geological Survey, ${ }^{2}$ U.S. Fish and Wildlife Service, ${ }^{3}$ University of California, Davis, ${ }^{4}$ U.S. Fish and Wildlife Service, Recovery Branch, ${ }^{5}$ East Bay Regional Park District, ${ }^{6}$ Invasive Spartina Project, ${ }^{7}$ California State Coastal Conservancy, ${ }^{8}$ San Francisco Estuary Invasive Spartina Project, ${ }^{9}$ Olofson Environmental Inc., ${ }^{10}$ Department of Evolution and Ecology, University of California, Davis, ${ }^{11}$ Point Blue Conservation Science,

${ }^{12}$ National Audubon Society 
view habitat condition as a necessary component for the continued persistence of populations or individuals. Each approach treats its desired outcome as a form of currency to measure change, e.g., more individuals of an endangered species or less area of invaded habitat, and the ecological processes that govern the system act as market forces to change each currency. Management actions, such as restoration, operate like any market manipulation and can result in natural trade-offs wherein one approach may receive benefit at the expense of the other. This apparent mismatch in the scale of desired outcomes is driven in part by philosophical differences between ecosystem restoration and species protection goals and the legal frameworks that govern them. International conventions have been developed that require party countries to "promote the protection of ecosystems, natural habitats and the maintenance of viable populations of species in natural surroundings" and "rehabilitate and restore degraded ecosystems and promote the recovery of threatened species" (United Nations Environment Programme 1992: articles 8d and 8f). In contrast to these statements, in practice the emphasis for restoration is often on natural/native species composition, or restoring ecological structure, and not on the restoration of ecosystem functions or processes that some argue should be the focus (Bradshaw and Chadwick 1980). Furthermore, the ability to return ecosystems to a prior reference condition is not always possible, particularly after extended periods of degradation (Duarte et al. 2009). Standards for restoration prioritization are often not well defined, either scientifically or legally (Alexander et al. 2011). This is particularly true within the United States where environmental laws predate modern ecosystem concepts resulting in a compartmentalized approach to regulation (Bruskotter et al. 2012).

The pre-eminent law governing protection of species or populations of species in the United States is the 1973 Endangered Species Act (ESA; U.S. Fish and Wildlife Service 1973). From its inception, the ESA was designed "to provide a means whereby the ecosystems upon which endangered species and threatened species depend may be conserved" (Sect. 2, para. b). There is no provision within the ESA that defines that habitat be composed of only native or naturally occurring physical or biological features, only that "critical habitat" is "essential to conservation of the species and which may require special management considerations or protections" (Sect. 3, para. 5A). In other words, critical habitat and native habitat are not synonymous. In many real-world situations, this lack of consistency results in little disparity between ecosystem restoration and endangered species management. However, notable controversies have occurred across a wide variety of taxa and environments, particularly when endangered species use non-native invasive species for food or shelter or when restoration actions harm a species or its habitat, e.g., the Kanab ambersnail (Oxyloma haydeni kanabensis; Stevens et al. 2001), the Southwestern Willow Flycatcher (Empidonax traillii extimus; Hatten and Paradzick 2003, Owen et al. 2005), the tidewater goby (Eucyclogobius newberryi; King et al. 2006), and the Mexican Spotted Owl (Strix occidentralis lucida; Prather et al. 2008). The phenomenon of endangered species facilitation by non-native species presents a management challenge that results in a conflict between the goals of ecosystem restoration and species preservation (e.g., U.S. Fish and Wildlife Service 1997, Van Riel et al. 2000). Such conflicts have resulted in court battles, delayed restoration, increased costs, and seemingly nonsensical management actions that are required to meet regulatory requirements (Meretsky et al. 2000, Roemer and Wayne 2003). For example, efforts to remove the Aleutian Cackling Goose (Branta hutchinsii leucopareia) from protections were delayed for years because initial recovery criteria required specific winter habitat conservation objectives that were not met despite total population sizes that were five times those required for delisting (Doremus and Pagel 2001).

Non-native invasive species have the potential to dramatically alter ecosystems, decrease native biodiversity, and further threaten imperiled species (Vitousek et al. 1996, Wilcove et al. 1998, Mack et al. 2000). In extreme cases, a single non-native plant species can completely displace the pre-existing native flora, fundamentally alter ecosystem function (Myers 1983, DiTomaso 2000, Grosholz et al. 2009), and act as an "ecosystem engineer" through the formation of novel habitat (Watling et al. 2011). The potential for non-native invasive species to cause irreversible impacts on ecosystem function often results in focused efforts on eradication (Pimentel et al. 2005). However, logistical challenges in eradicating a well-established invasive species may make containment and perpetual management a more realistic objective in many cases (Mack et al. 2000, Zavaleta et al. 2001). Neither approach recognizes the facilitative interactions that nonnative species may have with native biota (Richardson et al. 2000, Rodriguez 2006), and the resulting conflict between ecosystem restoration and species conservation goals may seem intractable. Just such a conflict arose in San Francisco Bay (hereafter, SF Bay) where salt marsh ecosystem restoration plans included the eradication of an invasive hybrid cordgrass (Spartina alterniflora $\times$ Spartina foliosa; hereafter, invasive Spartina) used for cover and nesting by an endangered bird, the California Ridgway's Rail (Rallus obsoletus obsoletus; hereafter, California rail). Our goal is to use this case study system as an exemplar of the complex management problems created when endangered species management objectives and ecosystem restoration management plans are in conflict. Because of a lack of synthesis among existing unpublished reports and archived data, it was necessary to provide a meta-analysis of all existing California rail population data to inform this case study. Therefore, we present a meta-analysis of California rail population trends and invasive Spartina eradication data that will describe the complex interrelationship between endangered California rails and non-native Spartinadominated habitats.

\section{Invasive Spartina and the California rail in San Francisco Bay}

The California rail is a secretive marsh bird endemic to tidal marsh habitat in SF Bay, a habitat that has been largely lost. Although there are many specific causes of marshland loss in SF Bay, most boil down to direct conversion to human uses and subsequent changes to ecological processes that maintained tidal marshes historically (Booker 2013). From the initial reclamation of marshlands for agriculture and salt production and urban fill during the settlement period and the Gold Rush, and continuing through into the early 20th century, the pace and scope of development and urbanization on former tidal marshes accelerated into the 1970s until today when the predominantly urban landscape of the SF Bay region is now dependent on those past irreversible actions (Booker 2013). These combined impacts to the native tidal marsh ecosystem have resulted in a loss of more 
than $80 \%$ of marshland habitat (San Francisco Bay Area Wetlands Ecosystem Goals Project 1999).

At the turn of the 19th century, tidal wetlands were abundant, and the California rail was commonly hunted and could be found on the menu of San Francisco dining establishments (Kennerly 1859). The California rail was abundant in all marshes in the estuary (Cohen 1895) and could also be found in Humboldt Bay (Gill 1979, Grinnell and Miller 1994), Elkhorn Slough (Silliman et al. 1915), and Morro Bay (Brooks 1940). However, by the early 1970s, the combined effects of conversion of tidal marsh to diked lands for agriculture and salt production (San Francisco Bay Area Wetlands Ecosystem Goals Project 1999), urban encroachment (U.S. Fish and Wildlife Service 2013), predation by both native and non-native predators (Harding et al. 2001), and contaminants such as mercury (Schwarzbach et al. 2006, Ackerman et al. 2012) put the species on the precursor to the endangered species list with as many as 4200 to 6000 California rails remaining (Gill 1979). The population continued to decline into the 1990s to fewer than a thousand individuals occurring only within SF Bay attributable in part to predation by non-native red fox (Vulpes vulpes; Albertson 1995, Garcia 1995, Foin et al. 1997, Harding et al. 2001). It was at about this time, coincident with predator management and habitat restoration (Albertson and Evens 2000) when the California rail's decline abated and populations began to recover, that a relatively overlooked plant, invasive Spartina, started a 20-year march into California rail habitats throughout south SF Bay.

The first record of non-native smooth cordgrass ( $S$. alterniflora) in SF Bay occurred in the early 1970s when the U.S. Army Corps of Engineers planted it at Coyote Hills Slough near Fremont, California (Callaway and Josselyn 1992). S. alterniflora largely went unnoticed until it began hybridizing with the native $S$. foliosa about a decade later (Ayres et al. 2004), resulting in invasive Spartina, which grows taller, more densely, and both higher and lower in elevation on the marsh plain than either parent species. Numerous species of cordgrass (Spartina spp.), in particular, have been identified globally as effective biological invaders, threatening a variety of natural ecosystems worldwide. The largest Spartina invasion in the world is also the most recent; $S$. alterniflora has invaded more than 112,000 ha of tidal salt marsh throughout eastern China and threatens migratory bird and local fish populations through displacement with mangrove forests or shallow water foraging habitats (Simenstad and Thom 1995, Wan et al. 2009), resulting in this species being placed on China's list of the 9 most harmful invasive alien plant species in 2003 (Wang et al. 2006). The largest invasion in the New World was by $S$. alterniflora in Willapa Bay, Washington, beginning ca. 1898. This invasion consisted of 3600 ha of Spartina interspersed within 27,000 ha of intertidal lands, and it is now all but eradicated from Willapa Bay (Strong and Ayres 2013). In SF Bay, invasive Spartina was invading tidal wetland areas, changing habitat structure, and expanding onto mudflats, creating tidal wetlands where none had existed previously (Daehler and Strong 1997, Rosso et al. 2005, Grosholz et al. 2009). The expansion of invasive Spartina paralleled California rail population trends (Albertson and Evens 2000, Liu et al. 2009, Overton 2013) as California rails sought refuge in the additional vegetative cover to hide from predators and build their nests.
Among most plant invasions worldwide, those caused by Spartina are recognized as particularly rapid invaders with quick growth and expansion because of phenological traits, often low levels of native species competition, and high levels of plasticity in ecological niches occupied (Strong and Ayres 2013). Over 26 years, $S$. alterniflora expanded more than 3 orders of magnitude along coastal regions of China from $2.6 \mathrm{~km}^{2}$ in 1985 to $4000 \mathrm{~km}^{2}$ in 2011 (Qiu 2013). A similar pattern occurred in SF Bay, where initially the reproductive output of invasive Spartina seemed to be limited by inbreeding depression and the Allee effect (Taylor et al. 2004). However, three factors, i.e., hybridization with native $S$. foliosa, increased seed production, and evolution of selffertility from nonselfing parent species, contributed substantially to the rapid spread of invasive Spartina throughout SF Bay (Callaway and Josselyn 1992, Antilla et al. 1998, Ayres et al. 2004, Sloop et al. 2009). Worldwide, invasions by Spartina spp. have resulted in altered benthic community structure (Hedge and Kriwoken 2000, Neira et al. 2006), conversion of low-marsh habitats to high-marsh habitats through increased accretion (Cottet et al. 2007), and reduction in mudflats, channels, and shorebird foraging habitats (Callaway and Josselyn 1992, Daehler and Strong 1997, Rosso et al. 2006). Invasive Spartina in SF Bay was also projected to negatively impact endangered plant and animal species, delay or prevent native salt marsh restoration or alter restoration trajectory toward non-native habitat conditions, and increase the risk of urban flooding from storm runoff (Strong and Ayres 2013).

The anticipated effects of Spartina expansion, as well as a potential means for control, had a regional antecedent in Willapa Bay, Washington, where $S$. alterniflora expanded throughout the estuary's mudflats. Initial control efforts failed during the first decade because of ineffective approaches, limited budgets, and insufficient scope of actions, but by 2004 new herbicide formulations and large-scale application were resulting in effective control. The rapid, and intensifying, spread of invasive Spartina in SF Bay lent a sense of urgency to the planning and implementation of potential responses. The lack of basic information on California rail biology, habitat requirements, population trends, and extent of use of invasive Spartina provided no effective check with which to balance these proposed responses to invasion, all of which were governed by the central mantra that native and natural is intrinsically better than invaded and artificial. The combined effect of these factors prompted the California State Coastal Conservancy and the U.S. Fish and Wildlife Service to establish the San Francisco Estuary Invasive Spartina Project (ISP) in 2000. The ISP's primary goal is to preserve and restore the ecological integrity of the estuary's intertidal habitats and estuarine ecosystem and prevent further degradation and loss of the natural ecological structure and function caused by invasive Spartina (California State Coastal Conservancy and U.S. Fish and Wildlife Service 2003). The ISP conducts annual surveys to map the distribution of invasive Spartina and collaborates with landowners and managers to implement site-specific treatment measures, such as the application of herbicide and restoration of native vegetation. These efforts have been focused primarily in the southern reach of SF Bay where the impacts of invasion were greatest. Herbicide treatments initially using glyphosate and then transitioning to imazapyr, a nonselective herbicide, along with mechanical 
eradication through digging and covering plants were a huge success at progressing toward ISP goals and reduced the invasion by more than $95 \%$ between 2005 and 2012 (Rohmer et al. 2014). Because of phenotypic similarity between invasive and native Spartina, restoration of native Spartina could not begin for a minimum of 3 years after complete and verified eradication of invasive Spartina from a marsh, though other native species could be restored when and where appropriate (California State Coastal Conservancy and U.S. Fish and Wildlife Service 2003).

The California rail population, however, also declined over this period, particularly where invasive Spartina eradication efforts were greatest between 2005 and 2008, because rail densities were generally higher in invaded marshes. However, declines were also reported in some uninvaded marshes far from Spartina eradication (Liu et al. 2009), but a comprehensive review of the overall population trends and effects of Spartina eradication was never formally completed. These findings did prompt a review of the ESA-required biological opinion that was part of the permitting requirements for the invasive Spartina eradication program. The main consequences from this review were new requirements to protect California rail populations and limits to where eradication efforts were to be allowed. Twenty-six marshes, encompassing more than half of the remaining invaded habitat, were put on a list of no-treatment areas in 2011. Ten of these marshes remain nontreatment zones to protect large constituent California rail populations that are reliant on large stands of invasive Spartina and contain some of the largest remaining stands of invasive Spartina. Prolonged periods without invasive Spartina eradication treatments in these no-treatment marshes may reverse some of the gains made not only within each notreatment area but also in adjacent areas through seed export driven by the tides.

Is this a case in which achieving ecosystem restoration goals conflicts with species preservation? Were environmental winners and losers selected because the ESA prioritizes one species over broader goals? Or, was this an example of successful adaptive ecosystem management, inadequacies and all? We examine the short-term effects of controlling invasive Spartina on California rail habitat and the associated changes in California rail density in SF Bay. Finally, we explore the apparent trade-offs between controlling a habitat-altering hybrid invasive plant species and protecting critically endangered California rails within the context of broader long-term goals, such as maintaining ecosystem function and promoting sustainable wildlife populations.

\section{METHODS}

\section{Study area}

Our study area encompassed SF Bay, the entire known breeding range of the California rail. We provide a broad meta-analysis of the relationships between California rail population change and habitat change resulting from Spartina eradication efforts throughout the species range in SF Bay. We provide a particular focus on California rail populations and invasive Spartina extent at 4 tidal salt marshes in the southern reach of SF Bay where detailed studies of California rail ecology occurred (Fig. 1): Arrowhead $\left(37^{\circ} 44.662^{\prime} \mathrm{N}, 122^{\circ} 12.832^{\prime} \mathrm{W}\right)$, Cogswell $\left(37^{\circ} 28.119^{\prime}\right.$ $\left.\mathrm{N}, 122^{\circ} 8.877^{\prime} \mathrm{W}\right)$, Colma $\left(37^{\circ} 38.682^{\prime} \mathrm{N}, 122^{\circ} 23.543^{\prime} \mathrm{W}\right)$, and
Laumeister $\left(37^{\circ} 28.311^{\prime} \mathrm{N}, 122^{\circ} 7.500^{\prime} \mathrm{W}\right)$. The regions containing these 4 marshes encompassed approximately $9.1 \%$ of known California rail habitat in SF Bay. Between 2005 and 2012, these regions contained approximately $25 \%$ of all individual California rails that were counted during annual population surveys throughout the species range. Arrowhead, Cogswell, and Colma contained high densities of invasive Spartina, whereas Laumeister contained a low density. California rail population monitoring (see Population monitoring) was conducted by multiple agencies, environmental consultants, and nongovernmental organizations at virtually all known habitat patches in SF Bay. Invasive Spartina was inventoried on an annual basis throughout the entire study area by the ISP.

Fig. 1. Locations that we evaluated include all sites where surveys were repeatedly conducted for California Ridgway's Rail from 2005 to 2012. Within each site, the extent of invasive Spartina was inventoried and treated annually by the Invasive Spartina Project, and the proportional reduction in Spartina cover attributable to treatment effects is displayed across 22 marsh complexes. Detailed studies of rail ecology were conducted at the 4 individual marshes identified by yellow arrows.

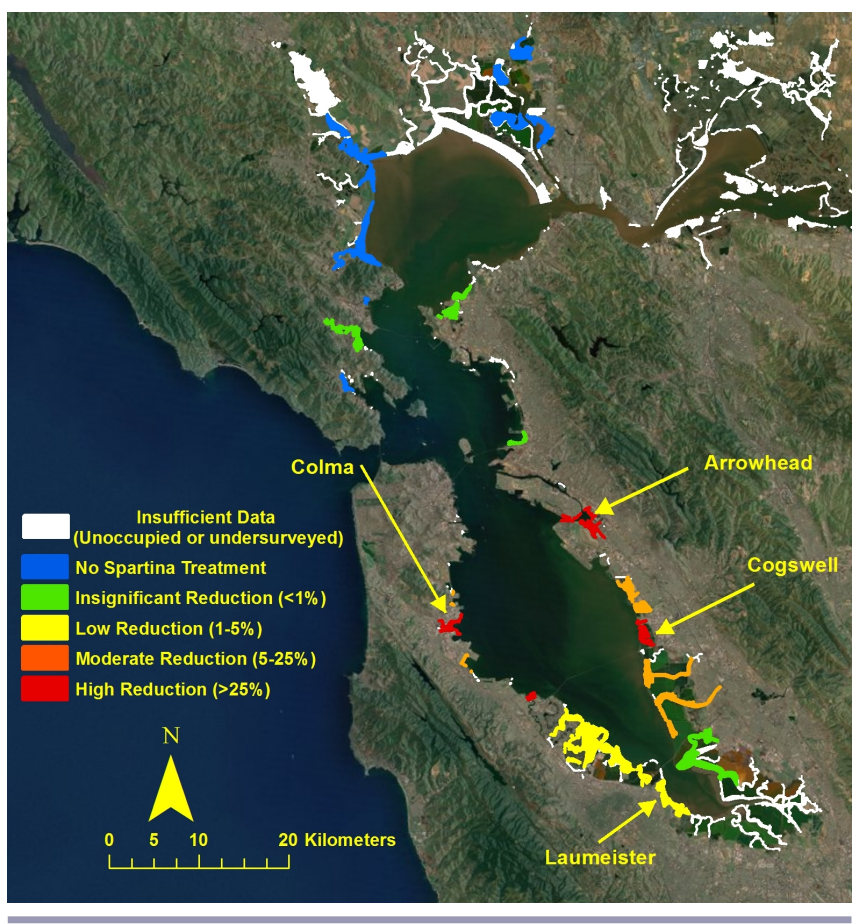

\section{Population monitoring}

Population monitoring surveys for California rails occurred at 141 marshes throughout SF Bay between 2005 and 2012 (Fig. 1). Call-count surveys were conducted by staff from Point Blue Conservation Science, Avocet Research Associates, the ISP, U.S. Fish and Wildlife Service, California Department of Fish and Wildlife, and East Bay Regional Park District (for details, see Liu et al. 2012, McBroom 2012). Our meta-analysis is the first attempt to consolidate these disparate data sources into a single peerreviewed meta-analysis and investigate population change in 
relation to habitat changes. Marshes were surveyed 3 to 5 times per year between January 15 and April 15 by experienced, permitted biologists using a point transect method, with at least 2 weeks between surveys at any given marsh. Listening stations were placed approximately $200 \mathrm{~m}$ apart and were primarily located at marsh edges, levees bordering and within marshes, boardwalks, and boat-accessible channels within the marsh. The number of listening stations established at each marsh varied because of site size, configuration, and accessibility. All rails, including California Ridgway's Rail, California Black Rail (Laterallus jamaicencis coturniculus), Virginia Rail (Rallus limicola), and Sora (Porzana carolina), detected from a listening station were recorded with the time, direction, and distance from the listening station, and the approximate locations of each California rail or pair of California rails were plotted on a field map of the site. Two passive surveys were conducted at each listening station during which a trained observer recorded all California rails detected visually or aurally for 10 minutes. If no California rails were detected within $200 \mathrm{~m}$ of a listening station during the passive surveys, playback (up to 1 minute) of California rail vocalizations was used to stimulate a response on a third survey. If a California rail responded during the broadcast call, the speakers and player were immediately turned off. California rails detected during transit between listening stations, as well as before or after the 10-minute listening period, were also recorded but not included in analyses. The standardized prerecorded vocalizations were provided by the U.S. Fish and Wildlife Service and were played from a compact disc or MP3 player with portable speakers. An additional survey method, high-tide counts, was used at Arrowhead Marsh and other marshes in the San Leandro region wherein boats were used during winter high tides to survey for California rails within flooded vegetation. High-tide counts are a postbreeding survey method conducted at the beginning of winter and prior to the period with highest California rail mortality (Overton et al. 2014). The difference in timing of the 2 survey methods results in a population trend estimated from high-tide counts that lag 1 year behind call-count trends (U.S. Geological Survey, unpublished data). Population trends estimated using both methodologies were averaged after accounting for this lag to provide a single measure of population change.

\section{Invasive Spartina eradication treatments}

Eradication treatments for invasive Spartina occurred in 99 marshes where California rail surveys occurred, mostly located in the southern reach of the SF Bay (Fig. 1). Staff from the ISP surveyed more than 20,000 ha of tidal marsh and mudflat around SF Bay on an annual basis to inventory invasive Spartina. Since 2008, all inventory has been conducted on the ground, i.e., on foot, by motorized boat, or by kayak, except for a few remote and heavily infested marshes that were periodically inventoried by helicopter. Each invasive Spartina occurrence was mapped using mobile GPS devices running ArcPad (ESRI, Redlands, CA) GIS software and summarized annually to produce an invasive Spartina extent for each marsh. Various methods to control invasive Spartina at our study sites began in 2005 and continued annually through 2012 during the months of May through November (Kerr and Grijalva 2012). Large-scale infestations that were distant from sensitive areas such as residential developments, schools, or hospitals were treated with broadcast aerial application of imazapyr herbicide. For those areas not large or continuous enough for broadcast aerial applications, either targeted aerial spot applications or ground-based treatment options, such as boats, amphibious vehicles, trucks, or backpack sprayers, were used. As the infestation of invasive Spartina became reduced, boat or ground-based applications became increasingly required to target remaining scattered invasive Spartina individuals. In a few areas with dense California rail populations, initial treatments included "seed suppression," whereby a diluted herbicidal solution was used so that flower and seed production were precluded but direct mortality of target plants was limited to retain vegetative cover for California rails (Kerr and Grijalva 2012).

\section{Population change analyses}

For our meta-analysis describing population changes in relation to invasive Spartina change, we consolidated individual marshes from those surveyed for population monitoring that were either contiguous or proximate to each other and received similar levels of herbicide treatment for invasive Spartina into 22 marsh complexes. The annual per capita rate of population change (lambda) was calculated from annual call counts totaled across complexes from 2005 to 2012 . This removed uninformative, i.e., random, site-level variation and enabled analysis of a larger proportion of total data. To compensate for missed counts, the rates of population change were proportionally weighted across marshes by the number of individuals detected. In 4 instances, the number of California rails detected in a complex was 0 , and because lambda in these instances was undefined, we removed those data from the analysis. We used generalized linear regression with random effects to estimate the rate of population change each year throughout SF Bay. We investigated the relationship between lambda and 3 invasive Spartina attributes: the year-toyear change in the extent of invasive Spartina in the marsh, the cumulative change in the amount of invasive Spartina from peak infestation, and the amount of invasive Spartina remaining in the marsh each year (Fig. 2).

Fig. 2. Average annual rate of California Ridgway's Rail population change between 2005 and 2012 relative to the cumulative change in extent of invasive Spartina within 22 marsh complexes in San Francisco Bay. Population rate of change expressed as the logarithm of lambda; positive values indicate population growth, and negative values indicate decline. Confidence interval, accounting for variance from fixed effects only, is represented by the dark gray interval. The prediction interval, which includes fixed effect and random slope variance, is represented by the light gray interval.

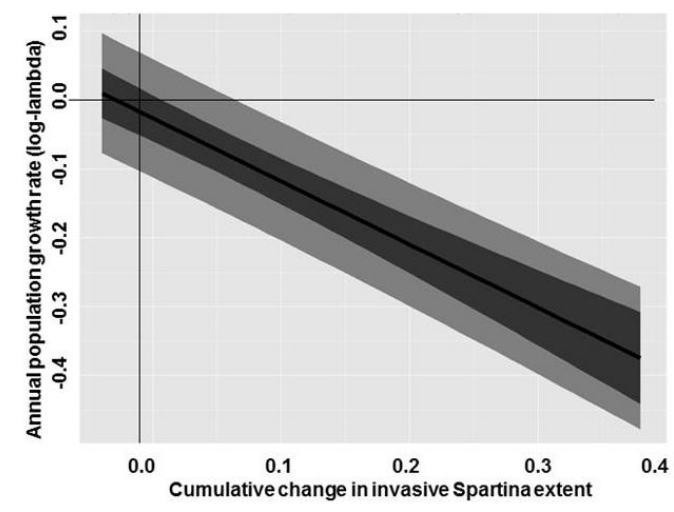


All invasive Spartina variables were expressed as the proportion of the total marsh surface area. Effects on California rail population growth rates caused by reduction in invasive Spartina cover may be moderated by the amount of invasive Spartina remaining or presence of other high-tide refugia in the marsh that rails can use; therefore, we also included models containing an interaction between changes in invasive Spartina, both annually and cumulatively, and the amount of remaining invasive Spartina. We evaluated the fit of all nested model structures using likelihood ratio tests and relative fit of "competing" main effects using Akaike's information criterion estimated using restricted maximum likelihood estimation, but inference was made on parameters estimated using full maximum likelihood estimation (Akaike's information criterion adjusted for small sample size [AICc]; Burnham and Anderson 2002, Bates et al. 2014). Random annual variation in the average lambda was included as a random intercept term. Because of the potential that annual variation may also influence the strength of fixed effects, we included a random slope parameter that allowed the strength of any invasive Spartina variables to change annually as well. The scope of our inference is to the population of California rails within the SF Bay, i.e., the range of counted sites and entire known breeding population, and not to the "average" population within the marshes where counts occurred. Therefore, we weighted lambdas by the number of California rails counted in each marsh complex to provide an unbiased estimate of population change throughout SF Bay. Analysis was performed using the lme4 package in Program R version 2.15.1 (R Development Core Team 2012, Bates et al. 2014).

To visualize relative invasive Spartina treatment effects, we categorized marshes into 5 levels based on the reduction in invasive Spartina area relative to marsh area: no treatment, insignificant reduction $(<1 \%)$, low reduction $(1 \%-5 \%)$, moderate reduction $(>5 \%-25 \%)$, and high reduction $(>25 \%)$. Binning Spartina treatment effects into categories was used only to provide visual display of the spatial extent of Spartina eradication effort, and our analysis did not use binned treatment levels. To display spatial examples of local Spartina treatment effects in select marshes, we used recent and historic imagery from the National Agriculture Imagery Program (http://www.fsa.usda.gov/programsand-services/aerial-photography/imagery-programs/naip-imagery/) and Google Earth (http://www.google.com/earth/) to visualize the extent of Spartina at each of the 4 study marshes. Imagery was chosen based on the month, year, and quality of the image for ease of analysis. Images were from spring or summer when invasive Spartina was in foliage and more easily discernible. Three years between 2005 and 2012 were chosen at sites where invasive Spartina control was implemented to illustrate the change in the extent of invasive Spartina over time.

\section{Capture and radiotelemetry}

We captured and radio marked 108 total California rails at Colma, Cogswell, and Laumeister Marshes between 2007 and 2009 to estimate movement, space use, and demographic rates (Rohmer 2010 , Overton et al. 2014). Sites typically had 10 or more radiomarked individuals during any given year except for Arrowhead Marsh, which was not included in capture efforts until the winter of 2008, and Laumeister Marsh, which was not trapped in 2009 and had only 2 remaining individuals radio marked during the previous year. Capture and radio marking occurred from
December to March at all sites, and we employed either dropdoor traps modified with fishing line trip wires or caught California rails by hand and with dip nets during the highest wintertime tides. California rails were fitted with 9.5-g backpack transmitters attached using modified Dwyer harnesses (Dwyer 1972). California rails were monitored intensively for the first 2 days after marking with repeated attempts at visually observing the bird to verify transmitter fit and acclimatization. Birds that survived between yearly capture sessions were recaptured and refitted with new transmitters after 10 to 13 months. California rail locations were determined 1 to 10 times per week with handheld 3-element Yagi antennas from the perimeter of the marshes at distances within a few hundred meters from the bird. Battery life of the radio was greater than 15 months, and each radio was tracked until the individual died or the radio failed. Locations of marked birds were triangulated using the programs Location of a Signal (Ecological Software Solutions LLC, Hegymagas, Hungary) and LOCATE III (Pacer Computing, Tatamagouche, Nova Scotia, Canada).

We examined whether population change (lambda) in a marsh varied according to the degree of invasive Spartina infestation and corresponding treatments. California rail survival is known to be low (Albertson 1995, Overton et al. 2014); however, dispersal capability throughout the species range is high but infrequent (Casazza et al. 2008). We determined whether rates of population change within individual marshes were driven by demographic processes or interchange among populations by investigating the rate of emigration from marshlands. We refer to "demographic processes" as the combined effects of survival and recruitment because we are unable to distinguish between these factors from a prebreeding call-count survey alone. In addition, we assume that the population change is affected only by the combined effects of demographic process and dispersal. Aerial telemetry flights were used to assist in locating transmitters that disappeared from a marsh to determine if California rails had dispersed.

\section{RESULTS}

Based on the annual California rail and invasive Spartina surveys, we estimated that California rail populations throughout SF Bay declined 9\% per year between 2005 and 2012, but declines were stronger where the most invasive Spartina treatment occurred (Fig. 2). Cumulative change in the amount of invasive Spartina within a marsh was a better predictor of California rail population change than year-to-year invasive Spartina changes $(\triangle \mathrm{AICc}=$ 3.33). California rail populations at sites not invaded by Spartina were estimated to have declined at an annual rate of $3 \%$ per year between 2005 and 2012. In comparison, at invaded sites, every $2.5 \%$ reduction in the marsh surface that was subject to invasive Spartina removal was associated with an additional $1 \%$ decline in subsequent California rail population growth rates. The addition of a term accounting for the amount of invasive Spartina remaining did not significantly improve our ability to estimate California rail population changes (likelihood ratio test, $p$ value $=0.237$ ). However, we note that although the parameters were not significant ( $\mathrm{p}=0.908)$, including an interactive effect between invasive Spartina cumulative changes and remaining invasive Spartina matched our hypothesis that California rail population growth rates declined at a lower rate when a greater proportion of the marsh remained occupied by invasive Spartina (lambda $=+3 \%$ for every $10 \%$ of marsh remaining as invasive Spartina). 
Of the 4 marshes where detailed California rail ecology was investigated, Colma Marsh showed the greatest proportional decrease in invasive Spartina and California rail call-count survey detections over time. The marsh had approximately 20.6 ha of invasive Spartina in 2005, 12.2 ha in 2008, and 0.02 ha in 2012 (Fig. 3A) as it returned to mudflat habitat, which is unsuitable for rail use. Call-count population surveys mirrored the decrease in invasive Spartina, with 63 birds detected in 2005, 35 in 2008, and 0 birds in 2012 (Fig. 3B). Cogswell Marsh was treated sequentially over time with the 2 western-most sections treated first and the eastern section treated last. Invasive Spartina was estimated at 43.4 ha in 2005, 14.6 ha in 2009, and 1.9 ha in 2012 (Fig. 4A) as the marsh vegetation state returned essentially to a young restoration site. Concurrently, Cogswell Marsh call-counts detected 40 birds in 2005, 28 in 2009, and 25 in 2012 (Fig. 4B). Arrowhead Marsh was completely covered with invasive Spartina in 2005 and then treated in sections with the western half treated first in 2008 and the eastern half included in the seed suppression treatments. Invasive Spartina treatment ceased in 2011, and 0.14 ha of regrowth was observed by 2012 in the western marsh. Arrowhead consisted of 9.2 ha of invasive Spartina in 2005, 7.5 ha in 2008, and 4.0 ha in 2012 (Fig. 5A). On average, call-count and high-tide surveys detected 72 birds in 2005, 112 in 2008, and 40 in 2012 in Arrowhead Marsh (Fig. 5B). Laumeister Marsh (37 ha) consisted of native marsh vegetation, including native Spartina. Almost no herbicide treatment was needed at Laumeister Marsh because only 2 small clones of invasive Spartina were present. Call-count detections were relatively stable since 2005 with no consistent trend (Fig. 6).

Fig. 3. Extent of habitats dominated by invasive Spartina delineated from aerial photography (shown in red) before treatment in 2005, after initial treatments in 2009, and after near eradication in 2012 (A); and call-count survey detections and trend ( -10.3 birds per year) within Colma Marsh (B).

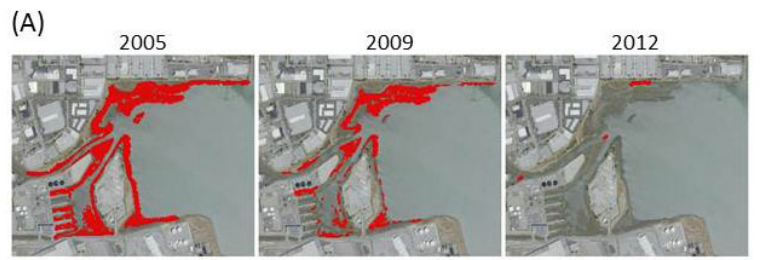

(B)

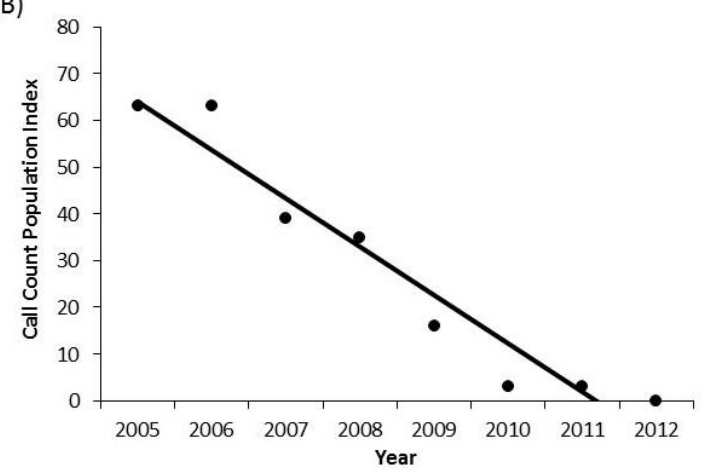

Fig. 4. Extent of habitats dominated by invasive Spartina delineated from aerial photography (shown in red) before treatment in 2005, after initial treatments in 2009 , and after near eradication in 2012 (A); and callcount survey detections and trend $(-5.8$ birds per year) within Cogswell Marsh (B).

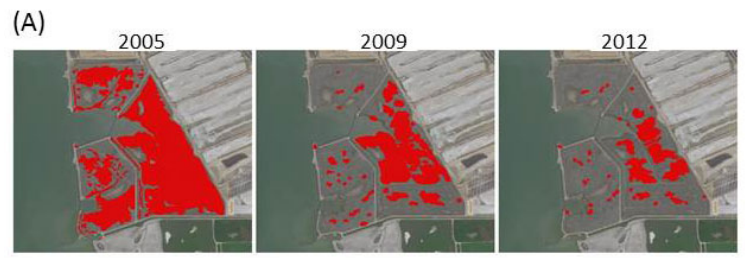

(B)

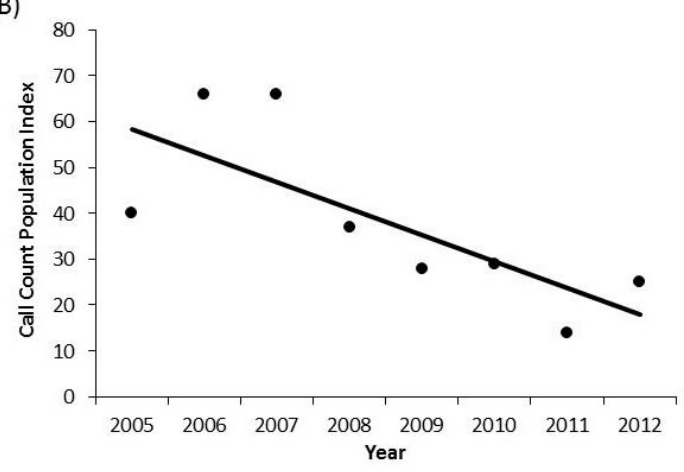

Fig. 5. Extent of habitats dominated by invasive Spartina delineated from aerial photography (shown in red) before treatment in 2005, after initial treatments in 2009, and after near eradication in 2012 (A); and callcount survey detections and trend $(-9.4$ birds per year) with Arrowhead Marsh (B).

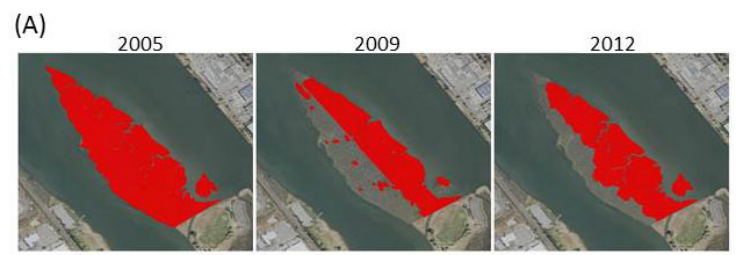

(B)

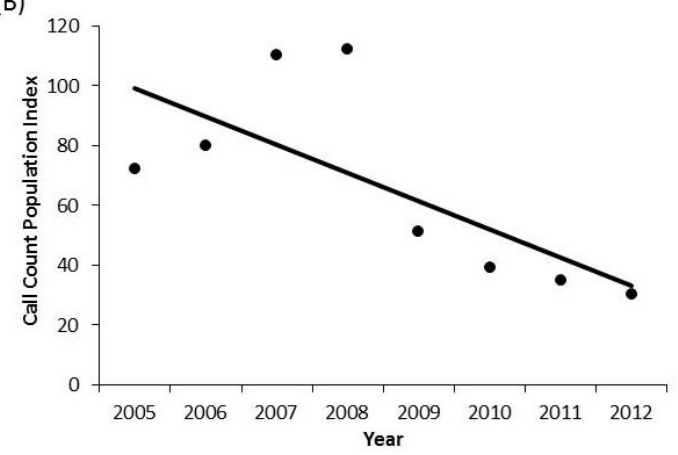


Fig. 6. California Ridgway's Rail call-count survey detections and trend $(-0.13$ birds per year) within Laumeister Marsh. Habitats dominated by invasive Spartina were virtually absent from Laumeister Marsh in all years (not shown).

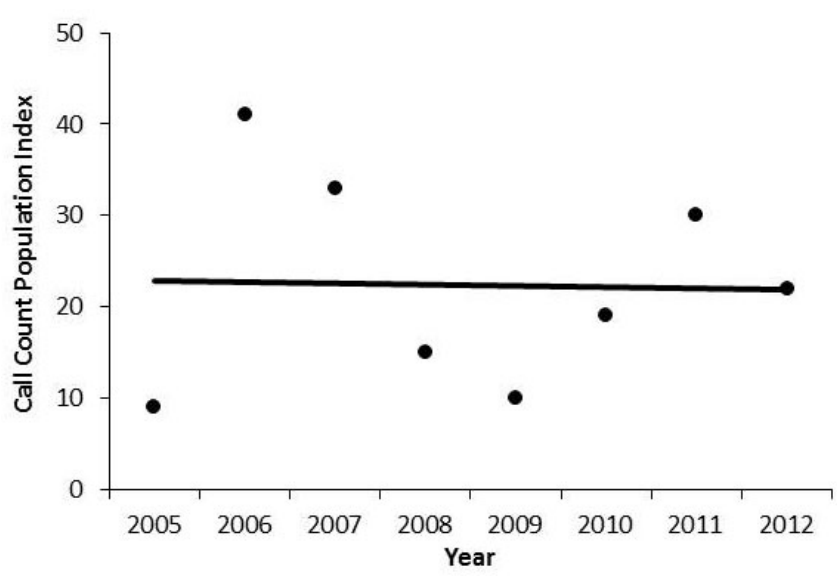

The vast majority of radio-marked California rails (104 out of 108) stayed within the marsh in which they were captured, indicating dispersal by California rails was rare. Only 4 radiomarked California rails were known to disperse to other marshes, and all left in the early breeding season. One rail dispersed from an invasive Spartina marsh (Colma) prior to treatment. Two California rails dispersed from the same marsh following eradication efforts, one of which established a new territory 45 $\mathrm{km}$ away and successfully bred in the same year following emigration (Casazza et al. 2008). The fourth individual dispersed from Cogswell Marsh prior to herbicide application in its territory, but after application elsewhere within the marsh. One of the later dispersing birds traveled a greater total distance, moving $45 \mathrm{~km}$ before backtracking $10 \mathrm{~km}$, where it remained for the subsequent breeding season and winter. The remaining birds traveled 11 and $12 \mathrm{~km}$, respectively.

\section{DISCUSSION}

California rail populations increased with the spread of invasive Spartina across SF Bay from the 1990s through 2008, and research suggests that the bird thrives in the habitat created by this invasive species (Overton et al. 2014, 2015). During the latter part of this period, many of the largest populations of California rails occurred in marshes heavily impacted by invasive Spartina. Although herbicide treatment between 2005 and 2012 removed invasive Spartina from open intertidal mudflats and preserved foraging habitat of shorebirds, removal of invasive Spartina from marshlands was partly responsible for the decreased California rail populations (Figs. 3-5). Estimated population change where Spartina eradication did not occur was still negative but not statistically different from 0 (Fig. 2). Across the entire species range, our estimated California rail declines between 2005 and 2012 (9\% per year) are similar to those obtained for $2005-2011$ using much of the same data but different methodologies (average $10 \%$ per year decline; Liu et al. 2012: Table 6). We found that dispersal of California rails was an uncommon event $(<4 \%$ of individuals emigrated) and did not occur with sufficient frequency to be responsible for the population changes observed (Figs. 3-6).
Within marshes where detailed study of California rail ecology occurred, only Laumeister Marsh, which had almost no invasive Spartina to eradicate, had no clear trend indicated by call-count surveys (Fig. 6). However, in marshes where invasive Spartina was present in large densities, populations declined rapidly commensurate with the amount of Spartina removed (Fig. 2). This meta-analysis corroborates previous work indicating that California rail survival was higher prior to invasive Spartina eradication than after eradication or compared to survival in a native marsh (Overton et al. 2014). The combined indication of these studies is that tall vegetation structure provides California rails with both higher quality nesting substrate and refuge cover from predation, particularly during high tides (Overton et al. 2014; U.S. Geological Survey, unpublished data). Thus, habitat structure provided by invasive Spartina in heavily infested marshes may facilitate California rail survival, and continued efforts to remove invasive Spartina from tidal salt marshes could lead to further California rail population declines unless other measures are taken to compensate for the loss in vegetative cover. Our metaanalysis makes clear that as implemented, management of the critically endangered California rail and management for a healthy SF Bay ecosystem without invasive Spartina resulted in a suite of incompatibilities that threatened both program goals.

The restoration of native SF Bay tidal marsh through the eradication of invasive Spartina has revealed a significant deficiency in the ecological functions that the current configuration of fragmented and degraded but uninvaded native habitats provides the California rail. In our efforts to restore healthy ecosystem functions to a suite of native species that may be at increased risk because of invasive Spartina, e.g., salt marsh harvest mouse (Reithrodontomys raviventris), soft bird's beak (Cordylanthus mollis), Pacific cordgrass ( $S$. foliosa), and more than 30 species of foraging shorebirds, we uncovered a previously unknown limitation, i.e., habitat quality, specifically quantity of tall vegetative cover, affecting 1 protected species. California rail populations throughout SF Bay were extremely reduced prior to the expansion of invasive Spartina and the novel habitat it created (Albertson and Evens 2000). Removing the source of that novel habitat without addressing pre-existing native habitat quality limitations threatens to re-create an ailing landscape for California rails by dogmatically adhering to specific management approaches. In essence, the conservation community is choosing the winners and losers in this ecosystem by failing to solve the underlying problems that will support a healthy species community with all constituent members. The extent to which species can respond to our management actions may be limited by intrinsic factors tied to the areas being managed. Mercury contamination in SF Bay, for example, exhibits clear patterns across space and within the macroinvertebrate food web that forms the California rail prey base (Ackerman et al. 2012, Casazza et al. 2014). Animals living in regions of elevated mercury concentrations or those feeding from portions of the food web with high bioaccumulated mercury levels may not respond to restoration actions as readily or rapidly as elsewhere in the species range because of physiological effects and demographic impairment of populations (Scheuhammer et al. 2007). How severe the nontarget effects of management actions become is partially influenced by these existing patterns of habitat fragmentation and degradation and may be compounded in the 
future because of projected increased habitat loss resulting from sea-level rise (Stralberg et al. 2011, Thorne et al. 2012, Swanson et al. 2014). Alone, these factors paint a very bleak future for the California rail; in the context of promoting a complete and healthy ecosystem, with limited resources and incomplete information, they create an almost impossible set of preconditions for success.

Ecosystem management, in general, and invasive species control, in particular, are complex issues, and decision making can be particularly challenging when an unnatural condition, such as the introduction of an invasive species or an altered disturbance regime, is detrimental to several native species but facilitates an endemic, endangered species (Rodriguez 2006). These types of management conflicts are becoming increasingly common (NRC 1995) whether invasive species are used for food by endangered species (King et al. 2006), habitat changes result in one endangered species depredating another (Gumm et al. 2008), or maintaining natural disturbance regimes affects critical habitat for an endangered species (Prather et al. 2008). A management conflict between ecosystem restoration and endangered species protection that parallels the situation surrounding invasive Spartina and California rails is the relationship between the endangered Southwestern Willow Flycatcher (E. trailii extimus) and the invasive salt cedar (Tamarix spp.). In the southwestern United States, the salt cedar significantly degrades native riparian ecosystems through soil salinization and narrowing of river channels, resulting in displacement of native vegetation and a decrease in biodiversity (Zavaleta 2000). However, the salt cedar also provides critical nesting habitat for the flycatcher (Hatten and Paradzick 2003, Owen et al. 2005) because much of the native cottonwood (Populus spp.) and willow (Salix spp.) habitat has been lost as a result of changing flood regimes and salinity levels. Therefore, eradication of salt cedar has the potential to negatively impact flycatcher populations, particularly during the reproductive season. Because of this conflict, salt cedar eradication has been delayed while other control strategies are devised (U.S. Fish and Wildlife Service 1997). Without restoration efforts that assure the re-establishment of native riparian vegetation and restoration of ecosystem function, the removal of invasive salt cedar will result in a loss of nesting habitat for the endangered flycatcher (Zavaleta et al. 2001, Dudley and DeLoach 2004, Sogge et al. 2008, Dudley and Bean 2012).

Should an invasive species be maintained when it benefits an endangered species to the detriment of native species and the ecosystem as a whole? Although the ESA specifically provides for the protection of species, focusing conservation efforts on a single indicator species potentially puts associated species at risk (Dudley and DeLoach 2004), especially if the indicator species does not accurately reflect overall ecosystem health (Landres et al. 1988). As an alternative to a single-species approach, some researchers have suggested targeting conservation efforts toward groups of similar species that collectively represent an ecosystem (Moyle 1995, Wiens et al. 2008, Suring et al. 2011, U.S. Fish and Wildlife Service 2013). However, criticisms have arisen suggesting that multispecies conservation planning efforts do not result in better outcomes for listed species (Clark and Harvey 2002). The increasing use of conservation approaches, such as habitat conservation plans and ecosystem management, that take into account whole assemblages of native flora and fauna, as well as abiotic, economic, and social factors, are therefore better suited to dealing with the complexity of conserving biological diversity (Pipkin 1996, Zipkin et al. 2010). Key features of ecosystem management are the focus on ecological processes, rather than on individual species, over large scales; the inclusion of humans as part of the ecosystem (Simberloff 1998); and the use of adaptive management whereby objectives and methods are modified as necessary to facilitate improved understanding of a system (Walters and Holling 1990). However, successful implementation of ecosystem management strategies faces many hurdles, including the lack of a consensus over what constitutes a healthy ecosystem (Wagner 1994), trade-offs between human consumption and conservation of natural resources (Kellner et al. 2011), insufficient collaboration between stakeholder groups with conflicting interests (Schultz et al. 2007), imperfect scientific understanding of management consequences, and an unfavorable socio-political climate (Rauscher 1999).

So does the perceived conflict between invasive Spartina eradication and California rail conservation constitute a failing of the ESA? Of ecosystem management? We do not think either of these are the case. Despite the delays, confusion, and increased urgency (and blood pressure) that these situations provoke, we suggest that these are exactly the types of disputes and ugly resolutions that functioning adaptive management entails when multiple management objectives are considered. Many of the previously discussed impediments became manifest in the current conflict between ecosystem restoration in SF Bay and management of the endangered California rail. The need for swift action was paramount because of the rapidly spreading invasive Spartina invasion and associated threats that were identified. At the time eradication was being implemented, two critical information gaps existed. First, there was insufficient information to predict the impact of Spartina eradication on the California rail, which was known to use invasive Spartina (California State Coastal Conservancy and U.S. Fish and Wildlife Service 2003, Overton 2010). Second, there was no quantitative estimation of how severe the impact to the tidal marsh ecosystem would be if no action was taken. These combined deficiencies resulted in a lack of a consensus on what the desired future conditions were and no clear benchmarks that would trigger a change or cessation of eradication activities.

The first information gap, invasive Spartina eradication effects on the California rail, was eventually filled in through directed research activities and extensively applied collaborative population monitoring, both of which quantified negative impacts and the ecological conditions that might avoid them. The speed with which Spartina treatment was implemented outpaced the speed at which we could identify impacts these treatments had on California rails as determined by population monitoring and directed research efforts. The second information gap, the effect on the tidal marsh ecosystem of doing nothing, could have been quantified prior to eradication actions, but the ensuing delay was considered risky in part because eradication costs and any impacts to tidal marsh ecology would increase as a result of delays. Therefore, no quantitative work was ever performed that would allow comparative risk assessment or similar decision-making guidance (Linkov et al. 2006). New knowledge about tidal marsh habitats in SF Bay that were not directly related not to Spartina issues but instead to expected future ecological conditions, e.g., sea-level rise, was also becoming available during this period. 
Downscaling of climate projections has resulted in growing concern that sea-level rise may influence California rail survival and habitat suitability (U.S. Fish and Wildlife Service 2013) through the reduction of habitat available as refuge cover for salt marsh-obligate species (Flick et al. 2003, NOAA 2009). Approximately $90 \%$ of marshland in SF Bay has been lost or converted to other land uses, causing reduction and fragmentation of remaining marshland (San Francisco Bay Area Wetlands Ecosystem Goals Project 1999), and SF Bay may lose the remaining high-marsh habitat that serves as refuge during extreme tides over the next century (Stralberg et al. 2011, Takekawa et al. 2013), unless sedimentation rates can increase to offset sea-level rise and thereby minimize loss of tidal refugia. Detailed analysis of California rail call-count surveys, habitats, and landscape conditions has increased our understanding of how marsh structure, surrounding landscapes, and restored marshland may influence California rail populations (Liu et al. 2009).

Climate change and large-scale restoration on California rail habitats also affect the large projects to restore former salt ponds in the north and south portions of SF Bay and habitat management in Suisun Bay as well. Invasive Spartina eradication is one approach in a larger effort to manage and enhance the salt marsh ecosystem of SF Bay. Other efforts that restore salt marsh formerly lost to development (South Bay Salt Pond Restoration Project, http://www.southbayrestoration.org/), reduce the effects of non-native predators (Albertson and Evens 2000), and improve habitat quality (ISP, http://www.spartina.org/; Save the Bay, http://www.savesfbay.org/) depend on the success of the Spartina eradication. Likewise, the direct adverse effects of Spartina eradication on California rail populations will be reduced by progress in these other efforts.

Several recommendations have been developed to mitigate negative effects of invasive species control on native bird communities and include maintaining existing uninvaded native habitats, restoring native vegetation, and balancing loss of nonnative habitat with adjacent native habitat (Paxton et al. 2011). Biological control may be a suitable method of invasive species control (Dudley and DeLoach 2004) where closely related native congeners do not exist. Within SF Bay, these recommendations have been implemented and augmented with large-scale restoration, the installation of artificial and earthen island habitats to replace tidal refuge and nesting cover for California rail (Overton et al. 2015; California State Coastal Conservancy, personal communication), supplemental native plantings, and herbicide-based seed suppression (Kerr and Grijalva 2012). These specific strategies may be useful to ameliorate conflicts once they become apparent, but compensating for the effects of management actions is not as efficient as preventing unintended consequences in the first place. Additional strategies are needed initially to ameliorate contradictory management goals.

An effective process for identifying and addressing conflicting ecosystem management goals is needed at the outset to avoid the types of conflicting goals that we encountered in SF Bay. Foremost among these strategies is broad recognition that both inaction and restoration actions constitute "interventions" within the increasingly human-altered ecosystem functions on which we focus our attentions (Ehrlich and Pringle 2008, Hobbs et al. 2011). Restoration goals need to be realistic, clearly outlined, and recognize where uncertainties exist without being "oversold" (Hobbs et al. 2011, Menz et al. 2013) to prevent the types of conflicting goals that have occurred in SF Bay and elsewhere (Noss and Michael 1997, Prather et al. 2008).

In light of the endangered species concerns, we have identified the following seven factors that would improve adaptive management of the salt marsh ecosystem:

- Start with coordinated and assimilated desired future conditions, development of best/alternative management actions, and how actions fit into ecosystem management plans; develop a consensus regarding the current state of knowledge for the topic at hand.

- Establish a clear consensus on baseline conditions or thresholds that will trigger management changes. These thresholds may include effects directly caused by intervention actions, e.g., direct take or mortality of individuals; indirectly caused by subsequent change to habitat or ecological processes, e.g., indirect take through harassment or habitat change; or even population trends caused by factors entirely outside the scope of interventions, e.g., climate-induced population declines or stochastic events.

- Identify information needed to support alternative management actions, e.g., risk assessments and resource and implementation monitoring, and establish funding and timeline to initiate projects.

- Use phased projects and evaluation of intermediate conditions or necessary preconditions that require additional intervention, i.e., what works in one area may not in another.

- Consider innovative methods and materials, e.g., artificial habitats, assisted migration, captive breeding, and intensive predator control.

- Quantify both negative effects and benefits to other ecosystem components for risk evaluation.

- Make use of collaboration and data sharing with common minimum standards and methods with consensus-driven interpretation and implication of findings.

Invasive Spartina eradication within SF Bay revealed that the native habitat condition among the degraded and fragmented remnant salt marsh was a relatively poor substitute compared to the vigorous invader, especially in lower elevation marshes containing few other sources of vegetative cover. In the effort to restore ecosystem health and function, the recovery objectives, indeed the very existence of the California rail, were at increased risk of failure following invasive species eradication. The biological opinion process designated through the ESA provided a critical re-evaluation of the functional role that invasive Spartina played in the existing salt marsh ecosystem and the deficiencies evident across many of the uninvaded fragmented marshlands. As mentioned by Zavaleta et al. (2001), invasive species eradication efforts may need checks, such as ESA enforcement, to prevent unintended and irreversible consequences to other ecosystem attributes such as preservation of endangered species. The success of the ESA and of adaptive ecosystem management 
is evident in the identification of problems associated with expeditious eradication and the rapid cooperation that led to alternative approaches. These alternative approaches may take longer (Lampert et al. 2014) and require more resources and cooperation to achieve, but they avoid the picking of winners and losers that runs counter to the central intents of ecosystem management (Grumbine 1994). The more measured approach we have outlined will reduce conflict between management goals and enhance the ability to affect positive, long-term ecosystem changes without sacrificing critical components in the short-term process.

Responses to this article can be read online at: http://www.ecologyandsociety.org/issues/responses. $\mathrm{php} / 8134$

\begin{abstract}
Acknowledgments:
This research was funded by the U.S. Geological Survey (USGS) and U.S. Fish and Wildlife Service (USFWS) joint Science Support Program and Quick Response Program, the Invasive Spartina Project, USFWS Coastal Program, and USFWS Sacramento Fish \& Wildlife Office. Ridgeway's Rail studies were permitted under USFWS endangered species permit TE-020548, California Department of Fish and Game Memorandum of Understanding and scientific collecting permits, USGS Bird Banding Laboratory permit 21142, and the USGS Western Ecological Research Center Animal Care and Use Committee. The use of trade, product, or firm names in the publication is for descriptive purposes only and does not imply endorsement by the U.S. government.
\end{abstract}

\section{LITERATURE CITED}

Ackerman, J. T., C. T. Overton, M. L. Casazza, J. Y. Takekawa, C. A. Eagles-Smith, R. A. Keister, and M. P. Herzog. 2012. Does mercury contamination reduce body condition of endangered California clapper rails? Environmental Pollution 162:439-448. http://dx.doi.org/10.1016/j.envpol.2011.12.004

Albertson, J. D. 1995. Ecology of the California clapper rail in the south San Francisco Bay. Thesis. San Francisco State University, San Francisco, California, USA.

Albertson, J. D., and J. B. Evens. 2000. California clapper rail. Pages 332-341 in P. R. Olofson, editor. Baylands ecosystems species and community profiles: life histories and environmental requirements of key plants, fish, and wildlife. San Francisco Bay Regional Water Quality Control Board, Oakland, California, USA.

Alexander, S., C. R. Nelson, J. Aronson, D. Lamb, A. Cliquet, K. L. Erwin, C. M. Finlayson, R. S. de Groot, J. A. Harris, E. S. Higgs, R. J. Hobbs, R. R. Robin Lewis III, D. Martinez, and C. Murcia. 2011. Opportunities and challenges for ecological restoration within REDD+. Restoration Ecology 19:683-689. http://dx.doi.org/10.1111/j.1526-100X.2011.00822.x

Antilla, C. K., C. C. Daehler, N. E. Rank, and D. R. Strong. 1998. Greater male fitness of a rare invader (Spartina alterniflora, Poaceae) threatens a common native (Spartina foliosa) with hybridization. American Journal of Botany 85:1597-1601. http:// dx.doi.org/10.2307/2446487

Ayres, D. R., D. L. Smith, K. Zaremba, S. Klohr, and D. R. Strong. 2004. Spread of exotic cordgrasses and hybrids (Spartina sp.) in the tidal marshes of San Francisco Bay, California, USA. Biological Invasions 6:221-231. http://dx.doi.org/10.1023/B: BINV.0000022140.07404.b7

Baker, W. L. 1992. The landscape ecology of large disturbances in the design and management of nature reserves. Landscape Ecology 7:181-194. http://dx.doi.org/10.1007/BF00133309

Bates, D., M. Maechler, B. Bolker, S. Walker, R. H. B. Christensen, H. Singmann, and B. Dai. 2014. Package lme4. R Foundation for Statistical Computing, Vienna, Austria.

Booker, M. 2013. Down by the bay: San Francisco's history between the tides. University of California Press, Berkeley, California, USA.

Bradshaw, A. D., and M. J. Chadwick. 1980. The restoration of land: the ecology and reclamation of derelict and degraded land. University of California Press, Berkeley, California, USA.

Brooks, A. 1940. The clapper rail of Morro Bay. Condor 42:126-127.

Bruskotter, J. T., S. A. Enzler, and A. Treves. 2012. Rescuing wolves: threat of misinformation-response. Science 335:795-796. http://dx.doi.org/10.1126/science.335.6070.795-b

Burnham, K. P., and D. R. Anderson, editors. 2002. Model selection and multimodel inference: a practical informationtheoretic approach. Springer-Verlag, New York, New York, USA. http://dx.doi.org/10.1007/b97636

California State Coastal Conservancy and U.S. Fish and Wildlife Service. 2003. San Francisco Estuary Invasive Spartina Project: Spartina Control Program. Volume 1, final programmatic environmental impact statementlenvironmental impact report. California State Coastal Conservancy, Oakland, California, USA; U.S. Fish and Wildlife Service, Sacramento, California, USA.

Callaway, J. C., and M. N. Josselyn. 1992. The introduction and spread of smooth cordgrass (Spartina alterniflora) in South San Francisco Bay. Estuaries 15:218-226. http://dx.doi.org/10.2307/1352695

Casazza, M. L., C. T. Overton, J. Y. Takekawa, T. Rohmer, and K. Navarre. 2008. Breeding behavior and dispersal of radiomarked California clapper rails. Western Birds 39:101-106.

Casazza, M. L., M. A. Ricca, C. T. Overton, J. Y. Takekawa, A. M. Merritt, and J. T. Ackerman. 2014. Dietary mercury exposure to endangered California Clapper Rails in San Francisco Bay. Marine Pollution Bulletin 86:254-260. http://dx.doi.org/10.1016/ j.marpolbul.2014.07.009

Clark, J. A., and E. Harvey. 2002. Assessing multi-species recovery plans under the Endangered Species Act. Ecological Applications 12:655-662. http://dx.doi.org/10.1890/1051-0761(2002)012[0655: AMSRPU $2.0 . \mathrm{CO} ; 2$

Cohen, D. A. 1895. The California clapper rail. Oologist 12:171-173. 
Conway, C. J., C. P. Nadeau, and L. Piest. 2010. Fire helps restore natural disturbance regime to benefit rare and endangered marsh birds endemic to the Colorado River. Ecological Applications 20:2024-2035. http://dx.doi.org/10.1890/09-1624.1

Cottet, M., X. de Montaudouin, H. Blanchet, and P. Lebleu. 2007. Spartina anglica eradication experiment and in situ monitoring assess structuring strength of habitat complexity on marine macrofauna at high tidal level. Estuarine, Coastal and Shelf Science 71:629-640. http://dx.doi.org/10.1016/j.ecss.2006.09.014

Daehler, C., and D. Strong. 1997. Hybridization between introduced smooth cordgrass (Spartina alterniflora; Poaceae) and native California cordgrass ( $S$. foliosa) in San Francisco Bay, California, USA. American Journal of Botany 84:607-611. http:// dx.doi.org/10.2307/2445896

D'Antonio, C., and L. A. Meyerson. 2002. Exotic plant species as problems and solutions in ecological restoration: a synthesis. Restoration Ecology 10:703-713. http://dx.doi.org/10.1046/ j.1526-100X.2002.01051.X

DiTomaso, J. M. 2000. Invasive weeds in rangelands: species, impacts, and management. Weed Science 48:255-265. http://dx. doi.org/10.1614/0043-1745(2000)048[0255:IWIRSI]2.0.CO;2

Doremus, H., and J. E. Pagel. 2001. Why listing may be forever: perspectives on delisting under the US Endangered Species Act. Conservation Biology 15:1258-1268.

Duarte, C. M., D. J. Conley, J. Carstensen, and M. SánchezCamacho. 2009. Return to Neverland: shifting baselines affect eutrophication restoration targets. Estuaries and Coasts 32:29-36. http://dx.doi.org/10.1007/s12237-008-9111-2

Dudley, T. L., and D. W. Bean. 2012. Tamarisk biocontrol, endangered species risk and resolution of conflict through riparian restoration. BioControl 57:331-347. http://dx.doi. org/10.1007/s10526-011-9436-9

Dudley, T. L., and C. J. DeLoach. 2004. Saltcedar (Tamarix spp.), endangered species, and biological weed control — can they mix? Weed Technology 18:1542-1551.

Dwyer, T. J. 1972. An adjustable radio-package for ducks. BirdBanding 43:282-284. http://dx.doi.org/10.2307/4511905

Ehrlich, P. R., and R. M. Pringle. 2008. Where does biodiversity go from here? A grim business-as-usual forecast and a hopeful portfolio of partial solutions. Proceedings of the National Academy of Sciences of the United States of America 105 (S1):11579-11586. http://dx.doi.org/10.1073/pnas.0801911105

Falk, D. A., C. I. Millar, and M. Olwell. 1996. Restoring diversity: strategies for reintroduction of endangered plants. Island, Washington, D.C., USA.

Flick, R. E., J. F. Murray, and L. C. Ewing. 2003. Trends in United States tidal datum statistics and tide range. Journal of Waterway, Port, Coastal, and Ocean Engineering 129:155-164. http://dx.doi. org/10.1061/(asce)0733-950x(2003)129:4(155)

Foin, T. C., E. J. Garcia, R. E. Gill, S. D. Culberson, and J. N. Collins. 1997. Recovery strategies for the California clapper rail (Rallus longirostris obsoletus) in the heavily-urbanized San Francisco estuarine ecosystem. Landscape and Urban Planning 38:229-243. http://dx.doi.org/10.1016/S0169-2046(97)00036-4
Garcia, E. J. 1995. Conservation of the California clapper rail: an analysis of survey methods and habitat use in Marin County, California. Thesis. University of California, Davis, Davis, California, USA.

Gill, R. 1979. Status and distribution of the California clapper rail (Rallus longirostris obsoletus). California Department of Fish and Game 65:36-49.

Grinnell, J. H., and A. H. Miller. 1994. The distribution of the birds of California. Pacific Coast Avifauna 27:1-608.

Grosholz, E. D., L. A. Levin, A. C. Tyler, and C. Neira. 2009. Changes in community structure and ecosystem function following Spartina alterniflora invasion of Pacific estuaries. Pages 23-40 in B. R. Silliman, E. D. Grosholz, and M. D. Bertness, editors. Human impacts on salt marshes. University of California Press, Berkeley, California, USA.

Grumbine, R. E. 1994. What is ecosystem management? Conservation Biology 8:27-38. http://dx.doi.org/10.1046/

j.1523-1739.1994.08010027.x

Gumm, J. M., J. L. Snekser, and M. Itzkowitz. 2008. Conservation and conflict between endangered desert fishes. Biology Letters 4:655-658. http://dx.doi.org/10.1098/rsbl.2008.0506

Harding, E. K., D. F. Doak, and J. D. Albertson. 2001. Evaluating the effectiveness of predator control: the non-native red fox as a case study. Conservation Biology 15:1114-1122. http://dx.doi. org/10.1046/j.1523-1739.2001.0150041114.X

Hatten, J. R., and C. R. Paradzick. 2003. A multiscaled model of southwestern willow flycatcher breeding habitat. Journal of Wildlife Management 67:774-788. http://dx.doi.org/10.2307/3802685

Hedge, P., and L. K. Kriwoken. 2000. Evidence for effects of Spartina anglica invasion on benthic macrofauna in Little Swanport estuary, Tasmania. Austral Ecology 25:150-159. http:// dx.doi.org/10.1046/j.1442-9993.2000.01016.X

Hobbs, R. J., L. M. Hallett, P. R. Ehrlich, and H. A. Mooney. 2011. Intervention ecology: applying ecological science in the twenty-first century. BioScience 61:442-450. http://dx.doi. org/10.1525/bio.2011.61.6.6

Kellner, J. B., J. N. Sanchirico, A. Hastings, and P. J. Mumby. 2011. Optimizing for multiple species and multiple values: tradeoffs inherent in ecosystem-based fisheries management. Conservation Letters 4:21-30. http://dx.doi.org/10.1111/j.1755-263X.2010.00132. $\underline{x}$

Kennerly, C. B. R. 1859. Route near the thirty-fifth parallel, explored by Lieutenant A.W. Whipple, topographical engineers, in 1853 and 1854: no. 3, report on birds collected on the route. Pacific Railroad Reports 10:19-35.

Kerr, J. T., and I. Deguise. 2004. Habitat loss and the limits to endangered species recovery. Ecology Letters 7:1163-1169. http:// dx.doi.org/10.1111/j.1461-0248.2004.00676.x

Kerr, D., and E. Grijalva. 2012. San Francisco Estuary Invasive Spartina Project treatment report for 2011. Prepared for California State Coastal Conservancy, San Francisco Estuary Invasive Spartina Project, Oakland, California, USA. [online] URL: http://www.spartina.org/documents/2011_Treatment_Report_FINAL. pdf 
King, R. B., J. M. Ray, and K. M. Stanford. 2006. Gorging on gobies: beneficial effects of alien prey on a threatened vertebrate. Canadian Journal of Zoology 84:108-115. http://dx.doi. org/10.1139/z05-182

Lampert, A., A. Hastings, E. D. Grosholz, S. L. Jardine, and J. N. Sanchirico. 2014. Optimal approaches for balancing invasive species eradication and endangered species management. Science 344:1028-1031. http://dx.doi.org/10.1126/science.1250763

Landres, P. B., J. Verner, and J. W. Thomas. 1988. Ecological uses of vertebrate indicator species: a critique. Conservation Biology 2:316-328. http://dx.doi.org/10.1111/j.1523-1739.1988.tb00195. $\underline{\mathrm{x}}$

Linkov, I., F. K. Satterstrom, G. Kiker, C. Batchelor, T. Bridges, and E. Ferguson. 2006. From comparative risk assessment to multi-criteria decision analysis and adaptive management: recent developments and applications. Environment International 32:1072-1093. http://dx.doi.org/10.1016/j.envint.2006.06.013

Liu, L., J. Wood, N. Nur, D. Stralberg, and M. Herzog. 2009. California Clapper Rail (Rallus longirostric obsoletus) population monitoring: 2005-2008. Final report. Prepared by PRBO Conservation Science for California Department of Fish and Game, Stockton, California, USA. [online] URL: http:// www.spartina.org/documents/Liu etal 2009 PRBOCLRAPopulation2005-2008.pdf

Liu, L., J. Wood, L. Salas, and N. Nur. 2012. 2011 Annual report to U.S. Fish and Wildlife Service: California Clapper Rail (Rallus longirostris obsoletus). TE-807078-12. PRBO Conservation Science, Petaluma, California, USA. [online] URL: http://www. prbo.org/cms/docs/wetlands/2011CLRA_USFWSReport_PRBO_FINAL. pdf

Ma, M., X. Zhou, and G. Du. 2011. Soil seed bank dynamics in alpine wetland succession on the Tibetan Plateau. Plant and Soil 346:19-28. http://dx.doi.org/10.1007/s11104-011-0790-2

MacDougall, A. S., and R. Turkington. 2005. Are invasive species the drivers or passengers of change in degraded ecosystems? Ecology 86:42-55. http://dx.doi.org/10.1890/04-0669

Mack, R. N., D. Simberloff, W. M. Lonsdale, H. Evans, M. Clout, and F. A. Bazzaz. 2000. Biotic invasions: causes, epidemiology, global consequences, and control. Ecological Applications 10:689-710. http://dx.doi.org/10.1890/1051-0761(2000)010[0689: BICEGC]2.0.CO;2

McBroom, J. 2012. California clapper rail surveys for the San Francisco Estuary Invasive Spartina Project. Prepared by Olofson Environmental Inc. for California State Coastal Conservancy, San Francisco Estuary Invasive Spartina Project, Oakland, California, USA. [online] URL: http://www.spartina.org/ project_documents/revegetation_program/CLRA\%20Report $\% 202012$. pdf

Menz, M. H. M., K. W. Dixon, and R. J. Hobbs. 2013. Hurdles and opportunities for landscape-scale restoration. Science 339:526-527. http://dx.doi.org/10.1126/science.1228334

Meretsky, V. J., D. L. Wegner, and L. E. Stevens. 2000. Balancing endangered species and ecosystems: a case study of adaptive management in Grand Canyon. Environmental Management 25:579-586. http://dx.doi.org/10.1007/s002670010045
Moyle, P. B. 1995. Conservation of native freshwater fishes in the Mediterranean-type climate of California, USA: a review. Biological Conservation 72:271-279. http://dx.doi.org/10.1016/0006-3207 (94)00089-9

Myers, R. L. 1983. Site susceptibility to invasion by the exotic tree Melaleuca quinquenervia in southern Florida. Journal of Applied Ecology 20:645-658. http://dx.doi.org/10.2307/2403532

National Oceanic and Atmospheric Administration (NOAA). 2009. Sea level variations of the United States 1854-2006. NOAA Technical Report NOS CO-OPS 053. U.S. Department of Commerce, Silver Spring, Maryland, USA.

National Research Council (NRC). 1995. Science and the Endangered Species Act. National Academy, Washington, D.C., USA.

Neira, C., E. D. Grosholz, L. A. Levin, and R. Blake. 2006. Mechanisms generating modification of benthos following tidal flat invasion by a Spartina hybrid. Ecological Applications 16:1391-1404. http://dx.doi.org/10.1890/1051-0761(2006)016[1391: MGMOBF]2.0.CO;2

Noss, R. F., and S. J. Michael. 1997. Ecosystem protection and restoration: the core of ecosystem management. Pages 239-264 in M. S. Boyce and A. Haney, editors. Ecosystem management: applications for sustainable forest and wildlife resources. Yale University Press, New Haven, Connecticut, USA.

Overton, C. T. 2010. Data summary: a review of literature regarding California clapper rail (Rallus longirostris obsoletus) demographics, habitat use, home range, movements, and effects of disturbance. Report prepared by U.S. Geological Survey for California State Coastal Conservancy, San Francisco Estuary Invasive Spartina Project, Berkeley, California, USA. [online] URL: http://www.spartina.org/project_documents/clapper_rails/ USGS CLRA Review.pdf

Overton, C. T. 2013. Tidally-induced limits to California clapper rail ecology in San Francisco Bay salt marshes. Dissertation. University of California, Davis, Davis, California, USA.

Overton, C. T., M. L. Casazza, J. Y. Takekawa, D. R. Strong, and M. Holyoak. 2014. Tidal and seasonal effects on survival rates of the endangered California clapper rail: does invasive Spartina facilitate greater survival in a dynamic environment? Biological Invasions 16:1897-1914. http://dx.doi.org/10.1007/s10530-013-0634-5

Overton, C. T., J. Y. Takekawa, M. L. Casazza, T. D. Bui, M. Holyoak, and D. R. Strong. 2015. Sea-level rise and refuge habitats for tidal marsh species: can artificial islands save the California Ridgway's rail? Ecological Engineering 74:337-344. http://dx.doi.org/10.1016/j.ecoleng.2014.10.016

Owen, J. C., M. K. Sogge, and M. D. Kern. 2005. Habitat and sex differences in physiological condition of breeding southwestern willow flycatchers (Empidonax traillii extimus). Auk 122:1261-1270. http://dx.doi.org/10.1642/0004-8038(2005)122\%5B1261:HASDIP $\%$ 5D2.0.CO;2

Paxton, E. H., T. C. Theimer, and M. K. Sogge. 2011. Tamarisk biocontrol using tamarisk beetles: potential consequences for riparian birds in the southwestern United States. Condor 113:255-265. http://dx.doi.org/10.1525/cond.2011.090226 
Pimentel, D., R. Zuniga, and D. Morrison. 2005. Update on the environmental and economic costs associated with alien-invasive species in the United States. Ecological Economics 52:273-288. http://dx.doi.org/10.1016/j.ecolecon.2004.10.002

Pipkin, J. 1996. Biological diversity conservation: a public policy perspective. Environmental Management 20:793-797. http://dx. doi.org/10.1007/BF01205958

Poff, N. L., J. D. Allan, M. B. Bain, J. R. Karr, K. L. Prestegaard, B. D. Richter, R. E. Sparks, and J. C. Stromberg. 1997. The natural flow regime. BioScience 47:769-784. http://dx.doi.org/10.2307/1313099

Poiani, K. A., B. D. Richter, M. G. Anderson, and H. E. Richter. 2000. Biodiversity conservation at multiple scales: functional sites, landscapes, and networks. BioScience 50:133-146. http://dx. doi.org/10.1641/0006-3568(2000)050[0133:BCAMSF]2.3.CO;2

Prather, J. W., R. F. Noss, and T. D. Sisk. 2008. Real versus perceived conflicts between restoration of ponderosa pine forests and conservation of the Mexican spotted owl. Forest Policy and Economics 10:140-150. http://dx.doi.org/10.1016/j.forpol.2007.07.003

Qiu, J. 2013. China's cordgrass plan is "overkill." Nature 499:392-393. http://dx.doi.org/10.1038/499392a

Rauscher, H. M. 1999. Ecosystem management decision support for federal forests in the United States: a review. Forest Ecology and Management 114:173-197. http://dx.doi.org/10.1016/S0378-1127 (98)00350-8

R Development Core Team. 2012. R: a language and environment for statistical computing. R Foundation for Statistical Computing, Vienna, Austria. [online] URL: http://www.R-project.org/

Rey Benayas, J. M., A. C. Newton, A. Diaz, and J. M. Bullock. 2009. Enhancement of biodiversity and ecosystem services by ecological restoration: a meta-analysis. Science 325:1121-1124. http://dx.doi.org/10.1126/science. 1172460

Richardson, D. M., N. Allsopp, C. M. D’Antonio, S. J. Milton, and M. Rejmanek. 2000. Plant invasions: the role of mutualisms. Biological Reviews 75:65-93.

Richter, B. D., and H. E. Richter. 2000. Prescribing flood regimes to sustain riparian ecosystems along meandering rivers. Conservation Biology 14:1467-1478. http://dx.doi.org/10.1046/ j.1523-1739.2000.98488.x

Rodriguez, L. F. 2006. Can invasive species facilitate native species? Evidence of how, when, and why these impacts occur. Biological Invasions 8:927-939. http://dx.doi.org/10.1007/ $\underline{\text { s10530-005-5103-3 }}$

Roemer, G. W., and R. K. Wayne. 2003. Conservation in conflict: the tale of two endangered species. Conservation Biology 17:1251-1260. http://dx.doi.org/10.1046/j.1523-1739.2003.02202. $\underline{x}$

Rohmer, T. M. 2010. Tracking the California clapper rail: a home range study in anticipation of imminent habitat change. Thesis, University of California, Davis, Davis, California, USA.

Rohmer, T., D. Kerr, and I. Hogle. 2014. San Francisco Estuary Invasive Spartina Project 2013 ISP monitoring and treatment report. Prepared for the California State Coastal Conservancy, Oakland, California, USA. [online] URL: http://www.spartina.
org/documents/2013MonitoringandTreatmentReport Fin-smmWEB 001.pdf

Rosso, P. H., S. L. Ustin, and A. Hastings. 2005. Mapping marshland vegetation of San Francisco Bay, California, using hyperspectral data. International Journal of Remote Sensing 26:5169-5191. http://dx.doi.org/10.1080/01431160500218770

Rosso, P. H., S. L. Ustin, and A. Hastings. 2006. A use of LiDAR to study changes associated with Spartina invasion in San Francisco Bay marshes. Remote Sensing of Environment 100:295-306. http://dx.doi.org/10.1016/j.rse.2005.10.012

San Francisco Bay Area Wetlands Ecosystem Goals Project. 1999. Baylands ecosystem habitat goals: a report of habitat recommendations. U.S. Environmental Protection Agency, San Francisco, California, USA; and San Francisco Bay Regional Water Quality Control Board, Oakland, California, USA.

Scheuhammer, A. M., M. W. Meyer, M. B. Sandheinrich, and M. W. Murray. 2007. Effects of environmental methylmercury on the health of wild birds, mammals, and fish. AMBIO: A Journal of the Human Environment 36:12-19. http://dx.doi.org/10.1579/0044-7447 (2007)36[12:eoemot]2.0.co;2

Schultz, L., C. Folke, and P. Olsson. 2007. Enhancing ecosystem management through social-ecological inventories: lessons from Kristianstads Vattenrike, Sweden. Environmental Conservation 34:140-152. http://dx.doi.org/10.1017/s0376892907003876

Schwarzbach, S. E., J. D. Albertson, and C. M. Thomas. 2006. Effects of predation, flooding, and contamination on reproductive success of California Clapper Rails (Rallus longirostris obsoletus) in San Francisco Bay. Auk 123:45-60. http:// dx.doi.org/10.1642/0004-8038(2006)123[0045:EOPFAC]2.0.CO;2

Silliman, O. P., C. M. Goethe, H. S. Swarth, W. L. Dawson, J. Dixon, D. I. Shepardson, H. C. Bryant, A. Brazier Howell, and W. M. Pierce. 1915. From field and study. Condor 17:201-207. http://dx.doi.org/10.2307/1362291

Simberloff, D. 1998. Flagships, umbrellas, and keystones: is single-species management passé in the landscape era? Biological Conservation 83:247-257. http://dx.doi.org/10.1016/S0006-3207 (97)00081-5

Simenstad, C. A., and R. M. Thom. 1995. Spartina alterniflora (smooth cordgrass) as an invasive halophyte in Pacific Northwest estuaries. Hortus Northwest 6:9-12, 38-40.

Sloop, C. M., D. R. Ayres, and D. R. Strong. 2009. The rapid evolution of self-fertility in Spartina hybrids (Spartina alterniflora $\times$ foliosa) invading San Francisco Bay, CA. Biological Invasions 11:1131-1144. http://dx.doi.org/10.1007/s10530-008-9385-0

Sogge, M. K., S. J. Sferra, and E. H. Paxton. 2008. Tamarix as habitat for birds: implications for riparian restoration in the southwestern United States. Restoration Ecology 16:146-154. http://dx.doi.org/10.1111/j.1526-100X.2008.00357.X

Stevens, L. E., T. J. Ayers, J. B. Bennett, K. Christensen, M. J. C. Kearsley, V. J. Meretsky, A. M. Phillips III, R. A. Parnell, J. Spence, M. K. Sogge, A. E. Springer, and D. L. Wegner. 2001. Planned flooding and Colorado River riparian trade-offs downstream from Glen Canyon Dam, Arizona. Ecological Applications 11:701-710. http://dx.doi.org/10.1890/1051-0761 (2001)011[0701:pfacrr]2.0.co:2 
Stralberg, D., M. Brennan, J. C. Callaway, J. K. Wood, L. M. Schile, D. Jongsomjit, M. Kelly, V. T. Parker, and S. Crooks. 2011. Evaluating tidal marsh sustainability in the face of sea-level rise: a hybrid modeling approach applied to San Francisco Bay. PLoS ONE 6:e27388. http://dx.doi.org/10.1371/journal.pone.0027388

Strong, D. R., and D. R. Ayres. 2013. Ecological and evolutionary misadventures of Spartina. Annual Review of Ecology, Evolution, and Systematics 44:389-410. http://dx.doi.org/10.1146/annurevecolsys-110512-135803

Suding, K. N. 2011. Toward an era of restoration in ecology: successes, failures, and opportunities ahead. Annual Review of Ecology, Evolution, and Systematics 42:465-487. http://dx.doi. org/10.1146/annurev-ecolsys-102710-145115

Suring, L. H., W. L. Gaines, B. C. Wales, K. Mellen-McLean, J. S. Begley, and S. Mohoric. 2011. Maintaining populations of terrestrial wildlife through land management planning: a case study. Journal of Wildlife Management 75:945-958. http://dx.doi. org/10.1002/jwmg.114

Swanson, K. M., J. Z. Drexler, D. H. Schoellhamer, K. M. Thorne, M. L. Casazza, C. T. Overton, J. C. Callaway, and J. Y. Takekawa. 2014. Wetland Accretion Rate Model of Ecosystem Resilience (WARMER) and its application to habitat sustainability for endangered species in the San Francisco Estuary. Estuaries and Coasts 37:476-492. http://dx.doi.org/10.1007/s12237-013-9694-0

Takekawa, J. Y., K. M. Thorne, K. J. Buffington, K. A. Spragens, K. M. Swanson, J. Z. Drexler, D. H. Schoellhamer, C. T. Overton, and M. L. Casazza. 2013. Final report for sea-level rise response modeling for San Francisco Bay estuary tidal marshes. Open File Report 2012-1081. U.S. Department of the Interior, U.S. Geological Survey, Reston, Virginia, USA. [online] URL: http:// pubs.usgs.gov/of/2013/1081/pdf/ofr20131081.pdf

Taylor, C. M., H. G. Davis, J. C. Civille, F. S. Grevstad, and A. Hastings. 2004. Consequences of an Allee effect in the invasions of a Pacific estuary by Spartina alterniflora. Ecology 85:3254-3266. http://dx.doi.org/10.1890/03-0640

Taylor, M. F. J., K. F. Suckling, and J. J. Rachlinski. 2005. The effectiveness of the Endangered Species Act: a quantitative analysis. BioScience 55:360-367. http://dx.doi.org/10.1641/0006-3568 (2005)055[0360:TEOTES]2.0.CO;2

Thorne, K. M., J. Y. Takekawa, and D. L. Elliott-Fisk. 2012. Ecological effects of climate change on salt marsh wildlife: a case study from a highly urbanized estuary. Journal of Coastal Research 28:1477-1487. http://dx.doi.org/10.2112/JCOASTRESD-11-00136.1

United Nations Environment Programme. 1992. Convention on Biological Diversity, 5 June 1992, Rio de Janeiro, Brazil. 1760 United Nations Treaty Series 79; 31 ILM 818. United Nations, New York, New York, USA.

U.S. Fish and Wildlife Service. 1973. United States list of endangered fauna. Office of Endangered Species and International Activities, U.S. Fish and Wildlife Service, Washington, D.C., USA.

U.S. Fish and Wildlife Service. 1997. Endangered and threatened wildlife and plants; final determination of critical habitat for the southwestern willow flycatcher. Federal Register 62:39129-39147.
U.S. Fish and Wildlife Service. 2013. Recovery plan for tidal marsh ecosystems of Northern and Central California. U.S. Fish and Wildlife Service, Sacramento, CA, USA.

Van Riel, P., K. Jordaens, A. M. Frias Martins, and T. Backeljau. 2000. Eradication of exotic species. Trends in Ecology \& Evolution 15:515. http://dx.doi.org/10.1016/S0169-5347(00)02007-3

Venter, O., N. N. Brodeur, L. Nemiroff, B. Belland, I. J. Dolinsek, and J. W. A. Grant. 2006. Threats to endangered species in Canada. BioScience 56:903-910. http://dx.doi.org/10.1641/0006-3568 (2006)56[903:TTESIC]2.0.CO;2

Vitousek, P. M., C. M. D'Antonio, L. L. Loope, and R. Westbrooks. 1996. Biological invasions as global environmental change. American Scientist 84:468-478.

Wagner, M. R. 1994. The healthy multiple-forest ecosystem: an impossible dream. Pages 185-188 in W. W. Covingont and L. F. DeBano, editors. Sustainable ecological systems: implementing an ecological approach to land management. U.S. Department of Agriculture, Fort Collins, Colorado, USA.

Walters, C. J., and C. S. Holling. 1990. Large-scale management experiments and learning by doing. Ecology 71:2060-2068.

Wan, S., P. Qin, J. Liu, and H. Zhou. 2009. The positive and negative effects of exotic Spartina alterniflora in China. Ecological Engineering 35:444-452. http://dx.doi.org/10.1016/j.ecoleng.2008.05.020

Wang, Q., S. Q. An, Z. J. Ma, B. Zhao, J. K. Chen, and B. Li. 2006. Invasive Spartina alterniflora: biology, ecology, and management. Acta Phytotaxonica Sinica 44:559-588.

Watling, J. I., C. R. Hickman, and J. L. Orrock. 2011. Invasive shrub alters native forest amphibian communities. Biological Conservation 144:2597-2601. http://dx.doi.org/10.1016/j.

biocon.2011.07.005

Wiens, J. A., G. D. Hayward, R. S. Holthausen, and M. J. Wisdom. 2008. Using surrogate species and groups for conservation planning and management. BioScience 58:241-252. http://dx.doi. org/10.1641/b580310

Wilcove, D. S., D. Rothstein, J. Dubow, A. Phillips, and E. Losos. 1998. Quantifying threats to imperiled species in the United States. BioScience 48:607-615. http://dx.doi.org/10.2307/1313420

Zavaleta, E. S. 2000. Valuing ecosystem services lost to Tamarix invasion in the United States. Pages 261-300 in H. A. Mooney and R. J. Hodds, editors. Invasive species in a changing world. Island, Washington D.C., USA.

Zavaleta, E. S., R. J. Hobbs, and H. A. Mooney. 2001. Viewing invasive species removal in a whole-ecosystem context. Trends in Ecology \& Evolution 16:454-459. http://dx.doi.org/10.1016/ $\underline{\mathrm{s} 0169-5347(01) 02194-2}$

Zedler, J. B. 1999. The ecological restoration spectrum. Pages 301-318 in W. Streever, editor. An international perspective on wetland rehabilitation. Kluwer Academic, Dordrecht, The Netherlands. http://dx.doi.org/10.1007/978-94-011-4683-8 29

Zipkin, E. F., J. Andrew Royle, D. K. Dawson, and S. Bates. 2010. Multi-species occurrence models to evaluate the effects of conservation and management actions. Biological Conservation 143:479-484. http://dx.doi.org/10.1016/j.biocon.2009.11.016 